\title{
Perubahan Volume Tumor, Jumlah Trombosit dan Kadar D-dimmer pada Karsinoma Payudara Lanjut Lokal Setelah Kemoterapi Neoadjuvan
}

\author{
Fredy Rustomi Damanik, Maman Abdurahman, Kiki Akhmad Rizki
}

\begin{abstract}
Locally advanced breast cancer places approximately 40-60\% from all the new cases of breast cancer in developing countries. And this kind of breast cancer requires a combined therapy, i.e. chemotherapy, surgery and radiotherapy. Nowadays, the response of chemotherapy is evaluated from the reduction in tumor volume. There is also another parameter. Since half of patients with breast cancer show abnormalities of routine blood clotting factors, D-dimmer which is a fibrin degeneration product from vascular endothelial growth factor (VEGF) is used. There is an increase of plasma D-dimmer level among $86 \%$ of breast cancer patients. There is a strong relationship amongst serum VEGF and platelets count in breast cancer patient. To analyze the correlation, we did an evaluation of the tumor volume, platelets count, and plasma D-dimmer among patients with locally advanced breast cancer, before and after cyclophospamide, doxorubicin, 5-fluorouracil (FAC) combined neoadjuvant chemotherapy. This was a prospective study enrolling 36 subjects. The data is obtained from the history, physical examination, laboratory and or radiological exams as it found in medical record. To have a normal distribution of the subjects, a Shapiro-Wilk test was done. Pearson correlation test was applied in evaluation of the relationship of tumor volume, platelet count and plasma D-dimmer level after chemotherapy. Data was analyzed using the SPSS program ver. 19.

The results of this study show that tumor volume decreases till $153.811 \mathrm{~cm} 3$, the platelet level decreased till 4,958.333/mm3 and the plasma D-dimmer level also decreased up to101.389 $\mathrm{ng} / \mathrm{mL}$ after FAC regimen. A significant relationship was found in platelet counts and tumor volume after chemotherapy with $r$ of 0.391 $(p=0.018)$. The relationship amongst the change in platelet level and plasma D-dimmer level showed a plateau which is quiet high with the value of $r=0.473(p=0.024)$.

In conclusion, there is a positive correlation of the tumor volume, the platelet level, and plasma D-dimmer level after combined FAC neoadjuvant chemotherapy (J I Bedah Indones. 2014;43:23-28).
\end{abstract}

Key words: Tumor volume, platelet count, D-dimmer, tumor volume, locally advanced breast cancer, chemotherapy.

\begin{abstract}
Abstrak
Diperkirakan 40-60\% dari keseluruhan kasus baru karsinoma payudara (KPD) di negara berkembang merupakan karsinoma payudara lanjut lokal (KPLL). Penanganan KPLL memerlukan modalitas terapi kombinasi, yaitu kemoterapi, pembedahan, dan radioterapi. Setengah dari seluruh penderita kanker, menunjukkan abnormalitas dari satu atau lebih parameter faktor rutin pembekuan darah. Respon kemoterapi selama ini dilihat berdasarkan pengurangan dari volume tumor. D-dimmer merupakan produk degenerasi fibrin dari vascular endothelial growth factor (VEGF), dan terdapat kenaikan kadar plasma D-dimmer pada 86\% penderita karsinoma payudara. Ada korelasi yang kuat antara kadar VEGF serum dengan jumlah trombosit pada penderita karsinoma payudara. Untuk menganalisis dan menilai hubungan yang ada, maka kami meneliti volume tumor, jumlah tombosit, dan kadar D-dimmer plasma pada penderita KPLL, sebelum dan sesudah

Alamat Korespondensi

Fredy Rustomi Damanik, dr.

Program Pendidikan Dokter Spesialis Bedah Departemen Ilmu Bedah

Fakultas Kedokteran Universitas Padjadjaran /

RSUP DR. Hasan Sakidin, Bandung

Email: rustogs@gmail.com

kemoterapi neoadjuvan kombinasi cyclophospamide, doxorubicin, 5-fluorouracil (FAC). Metode penelitian prospektif terhadap 36 subjek. Data penelitian di dapatkan dari anamnesis, pemeriksaan fisik, pemerik-
\end{abstract}


saan penunjang, dan rekam medis. Untuk menguji normalitas distribusi subjek penelitian digunakan ujiShapiro-Wilk. Uji korelasi Pearson dilakukan untuk menentukan hubungan antara perubahan volume tumor, jumlah trombosit, dan kadar D-dimmer plasma setelah pemberian kemoterapi. Data dianalisis dengan menggunakan program SPSS versi 19. Hasil penelitian didapatkan bahwa terdapat perubahan berupa penurunan volume tumor sebesar $153,811 \mathrm{~cm} 3$, penurunan jumlah trombosit sebesar 4.958,333/mm3, dan penurunan kadar D-dimmer plasma sebesar 101,389 ng/mL setelah kemoterapi FAC. Hubungan yang bermakna didapatkan antara perubahan jumlah trombosit dengan perubahan volume tumor setelah kemoterapi, $r=0,391$ $(\mathrm{p}=0,018)$. Hubungan dengan keeratan yang cukup tinggi juga didapatkan antara perubahan jumlah trombosit dengan perubahan kadar $\mathrm{D}$-dimmer, dengan nilai $\mathrm{r}=0,473(\mathrm{p}=0,024)$. Kesimpulan, terdapat korelasi positif antara perubahan volume tumor, jumlah trombosit, dan perubahan kadar D-dimmer plasma setelah kemoterapi neoadjuvan kombinasi FAC pada pasien KPLL (J I Bedah Indones. 2014;43:23-28)

Kata kunci: Volume tumor, trombosit, D-dimmer, volume tumor, karsinoma payudara lanjut lokal, kemoterapi.

\section{Pendahuluan}

Kanker payudara merupakan keganasan yang paling sering terdiagnosis pada wanita di seluruh $d u$ nia, dan kedua setelah kanker paru-paru pada semua jenis kelamin. Diperkirakan sekitar 1,38 juta wanita di seluruh belahan dunia terdiagnosis sebagai kan ker payudara pada tahun 2008, 23\% dari keseluruhan kejadian kanker pada wanita, dan menjadi penyebab terbanyak kematian pada wanita dengan 460.000 kematian selama tahun $2008{ }^{1}$

Menurut Informasi Kesehatan Rumah Sakit Departemen Kesehatan RI pada tahun 2008, kanker payudara menempati urutan pertama penyakit keganasan di Indonesia dengan proporsi 16,98\% dari seluruh keganasan. Perhimpunan Ahli Bedah Onkologi Indonesia rnemperkirakan paling sedikit 20.000 kasus baru karsinoma payudara setiap tahunnya dan lebih dari 50\% kasus sudah dengan stadium lanjut. ${ }^{2,3}$ Diperkirakan 10-20\% dari seluruh kasus karsinoma payudara termasuk ke dalam karsinoma payudara lanjut lokal. Penanganan karsinoma payudara lanjut lokal memerlukan pendekatan multidisiplin dan penggunaan modalitas terapi kombinasi yang terdiri dari kemoterapi, pembedahan, dan radioterapi. ${ }^{4,5,6}$

Pada awalnya pendekatan terapi karsinoma payudara lanjut lokal dimulai dengan pembedahan, radiasi, atau kombinasi keduanya, namun pendekatan ini tidak memberikan efek terhadap disease free survival atau overall survival yang optimal. Saat ini penanganan karsinoma payudara lanjut lokal diawali dengan pemberian kemoterapi neoadjuvan kemudian operasi dan dilanjutkan kemoterapi adjuvant. ${ }^{6,7}$

Kemoterapi neoadjuvan adalah pemberian obat antikarsinoma sebelum mendapatkan tindakan lokoregional dengan pembedahan, bertujuan agar tumor primer yang tidak resektabel dapat berubah menjadi resektabel sehingga memungkinkan untuk dilakukan mastektomi. ${ }^{4,6}$

Terdapat 2000 analisis yang terfokus pada evaluasi terhadap 14000 wanita yang berpartisipasi pada percobaan yang membandingkan regimen $\mathrm{CMF}$ (cyclophosphamide, methotrexate,5-fluorouracil) dengan regimen anthracycline- based, CAF/FAC (cyclophospamide, doxorubicin, 5-fluorouracil), dan didapatkan informasi bahwa penggunaan antrasiklin akan memberikan keuntungan yang signifikan pada penurunan rekurensi dan angka mortalitas 15 tahun. ${ }^{5}$ Respon kemoterapi selama ini dipantau secara klinis maupun radiologis, dilihat berdasarkan pengurang an volume tumor, yang dibagi atas respon komplit, respon parsial, stabil dan penyakit progresif. ${ }^{8}$

Pertumbuhan dari sebuah tumor solid dan metastasisnya sangat tergantung dari pembentukan pembuluh darah baru (angiogenesis). Kompleks interaksi antara sel tumor dan trombosit memainkan peranan penting di dalam proses ini. Trombosit adalah sumber utama dari VEGF, suatu protein pertumbuhan angiogenik poten yang berperan penting pada banyak proses patofisiologi, termasuk proses tumorigenesis..$^{9,10}$

Salah satu yang dominan dalam proses angioge nesis adalah VEGF-A, yang mampu memengaruhi 
permeabilitas kapiler sehingga menyebabkan ekstravasasi plasma, yang kemudian akan menstimulasi sistem koagulasi dan dengan bantuan faktor pembekuan darah lalu terbentuklah deposisi fibrin yang kemudian diikuti dengan proses degradasi. Salah satu produk akhir dari degradasi fibrin yang paling stabil adalah D-dimmer. ${ }^{11,12}$

Verheul dkk, 1997 melaporkan adanya korelasi yang kuat antara kadar VEGF serum dengan jumlah trombosit pada penderita karsinoma payudara. ${ }^{13}$ Dirix, 1999 mendapatkan kenaikan kadar plasma $D$-dimmer pada $86 \%$ penderita karsinoma payudara, ke adaan ini menggambarkan peningkatan aktivasi koagulan sel tumor dan invasi jaringan. ${ }^{14}$ Purwito (2011) melaporkan bahwa terdapat hubungan sangat kuat antara pemberian kemoterapi neoadjuvan kombinasi FAC terhadap penurunan kadar $D$-dimmer plasma dan penurunan volume tumor payudara pada penderita karsinoma payudara lanjut lokal di RSHS Bandung. ${ }^{15}$ Berdasarkan uraian di atas maka penulis tertarik untuk meneliti hubungan antara perubahan jumlah trombosit, kadar $D$-dimmer plasma, dan volume tumor penderita karsinoma payudara lanjut lokal setelah mendapat kemoterapi neoadjuvan kombinasi FAC, sehingga pemeriksaan hitung jumlah trombosit dapat digunakan bersamaan dengan pemeriksaan $\operatorname{kadar} D$ dimmer plasma sebagai alternatif prediktor penilaian respon kemoterapi.

\section{Metode}

Penelitian ini adalah suatu studi analitik observasional dengan desain prospektif untuk mengetahui hubu ngan antara perubahan jumlah trombosit, kadar Ddimmer plasma, dan volume tumor payudara setelah dilakukan kemoterapi neoadjuvan kombinasi FAC. Ukuran sampel ditentukan dengan koefisien korelasi sebesar 0,4 pada taraf kepercayaan $95 \%$ dan power of test $90 \%$, dan diperoleh ukuran sampel minimal 34 pasien.

Subjek penelitian adalah pasien karsinoma payudara stadium lanjut lokal di Divisi Bedah Onkologi dan Kepala-Leher, Departemen Ilmu Bedah RS Hasan Sadikin Bandung dengan kriteria inklusi pasien yang didiagnosis karsinoma payudara stadium lanjut lokal yang belum mendapat kemoterapi dan bersedia mengikuti penelitian. Kemoterapi neoadjuvan yang diberikan adalah regimen 5-fluorouracil $600 \mathrm{mg} / \mathrm{m} 2$, doxorubicin/adriamycin $60 \mathrm{mg} / \mathrm{m} 2$, cyclophosphamide $600 \mathrm{mg} / \mathrm{m} 2$ (FAC). Kriteria ekslusi antara lain pasien dengan kelainan jantung, pasien dengan sepsis, pasien kelainan darah. Semua pasien karsinoma payudara lanjut lokal yang memenuhi kriteria inklusi dan eksklusi diukur tumor payudaranya dengan jangka sorong dan diperiksa hitung jumlah trombosit dan kadar D-dimmer plasma sebelum dan sesudah pemberian kemoterapi neoadjuvan kombinasi FAC. Selanjutnya data dianalisis lebih lanjut.

\section{Hasil}

Terdapat 36 pasien yang memenuhi kriteria inklusi dan eksklusi dalam periode September 2013-Januari 2014 di Poli Rawat Jalan Divisi Bedah Onkologi dan Kepala-Leher RS Hasan Sadikin Bandung. Subjek penelitian memiliki rentang usia antara antara 29-70 tahun, memiliki rata-rata 49,61 tahun serta simpang baku 11,059 tahun. Distribusi usia penderita terba nyak adalah antara usia 51-60 tahun dengan 33\% dan paling sedikit adalah usia kurang dari 30 tahun dengan 3\%. Dari 36 subjek penelitian, terdapat 25 pasien yang memiliki hubungan berbanding lurus di antara variabel, yaitu ketika terjadi penurunan volume tumor akibat respon kemoterapi terjadi juga penurunan jumlah trombosit bersamaan dengan penurunan kadar Ddimmer plasma. Sedangkan untuk 11 subjek yang lain memiliki hubungan yang berbanding terbalik diantara variabel, yaitu terjadi peningkatan jumlah trombosit dan kadar $D$-dimmer plasma pada saat terjadi penurunan volume tumor.

Sebelum dilakukan uji statistik terhadap korelasi antara perubahan jumlah trombosit, kadar $D$-dimmer plasma, dan volume tumor payudara setelah kemoterapi, dilakukan uji distribusi data dengan menggunakan uji Shapiro-Wilk untuk melihat normalitas dari distribusi data hasil penelitian. Didapatkan semua variabel berdistribusi normal, dengan perubahan jumlah trombosit memiliki nilai $\mathrm{p}=0,137$, perubahan kadar D-dimmer plasma memiliki nilai $\mathrm{p}=0,051$, dan perubahan volume tumor memiliki nilai $\mathrm{p}=0,032$. 
Hasil uji normalitas tersebut dilakukan uji korelasi Pearson untuk mengetahui korelasi antar perubahan jumlah trombosit, kadar D-dimmer plasma dan volume tumor payudara setelah kemoterapi. Didapat kan perubahan berupa penurunan jumlah trombosit sebesar 4.958,333/mm3, penurunan kadar D-dimmer plasma sebesar $101,389 \mathrm{ng} / \mathrm{mL}$, dan penurunan volu me tumor sebesar $153,811 \mathrm{~cm} 3$ setelah kemoterapi FAC. Hubungan antara perubahan jumlah trombosit dengan perubahan kadar D-dimmer plasma memiliki keeratan yang cukup tinggi dengan nilai $r=0,473$ $(p=0,024)$. Hubungan yang bermakna juga didapatkan antara perubahan jumlah trombosit dengan perubahan volume tumor setelah kemoterapi, $r=0,391(p=0,018)$.

\section{Diskusi}

Berdasarkan data pada studi ini, terlihat adanya penurunan rerata jumlah trombosit, kadar D-dimmer, dan volume tumor payudara setelah dilakukan kemoterapi neoadjuvan kombinasi FAC. Perhitungan statistik menunjukkan bahwa terdapat hubungan yang signifikan antara perubahan jumlah trombosit dengan perubahan kadar D-dimmer plasma (nilai $\mathrm{p}=0,024$; nilai $r=0,473$ ) dan dengan perubahan volume tumor payudara (nilai $\mathrm{p}=0,018$; nilai $\mathrm{r}=0,391$ ).

Hal ini dapat diartikan bahwa pengurangan volume tumor payudara sebagai respon terhadap kemoterapi neoadjuvan kombinasi FAC dapat mengurangi aktivasi dan produksi trombosit, serta kadar D-dimmer plasma berkaitan dengan hubungan yang kuat antara angiogenesis dan sistem koagulasi di dalam memfasilitasi proses pertumbuhan dan metastasis karsinoma payudara. Hasil penelitian ini sejalan dengan teori bahwa volume dan metastasis tumor payudara berhubungan dengan perubahan jumlah trombosit dan kadar D-dimmer plasma, selain itu pertumbuhan dan metastasis tumor dapat dihambat oleh obatobatan kemoterapi. Benoy pada tahun 2005 menyata kan adanya peningkatan interaksi antara sel tumor, penjamu, peranan sitokin, parakrin, endokrin, interleukin-6, dan keterlibatan sistem koagulasi dalam pertumbuhan dan metastasis karsinoma payudara. ${ }^{16}$ Pada literatur disebutkan bahwa diperkirakan setengah dari seluruh penderita kanker, dan sebanyak $90 \%$ dari penderita kanker dengan metastasis menunjukkan abnormalitas dari satu atau lebih parameter rutin pembekuan, dengan yang paling sering terjadi adalah trombositosis (30-60\%). ${ }^{12}$

Hubungan antara peningkatan jumlah trombosit dan tumor ganas pertama kali dilaporkan oleh Reis pada tahun 1872. Penelitian berikutnya kemudian membuktikan hubungan ini untuk keganasan yang banyak terjadi, seperti keganasan pada kolorektal, paru-paru, dan payudara. D-dimmer plasma menjadi pertanda diagnosis yang bernilai tinggi untuk mendeteksi atau memonitor kejadian trombotik..$^{9,17}$

Penelitian Oya (2001) menyatakan bahwa kadar D-dimmer plasma meningkat sesuai dengan besarnya tumor. Teori dari Blackwell dan Dirix menyatakan adanya peningkatan kadar D-dimmer plasma pada penderita karsinoma payudara progresif dan adanya hubungan antara kadar D-dimmer plasma dengan stadium klinis karsinoma payudara..$^{18,19,20}$

Jika setiap subjek dilihat secara individu, memang didapatkan adanya 11 subjek penelitian yang masing-masing memiliki korelasi negatif atau hubungan yang berbanding terbalik. Hal ini mungkin terjadi karena waktu pemeriksaan hitung jumlah trombosit dan kadar D-dimmer plasma yang kurang tepat. Terdapat fluktuasi kadar VEGF setelah kemoterapi. VEGF memiliki memiliki keterkaitan yang erat dengan jumlah trombosit dan kadar D-dimmer. Verheul pada tahun 1997 melaporkan terjadinya penurunan kadar VEGF serum pada minggu awal setelah kemoterapi yang kemudian akan meningkat pada minggu ke-3 dan mencapai kondisi normal setelah minggu ke- $-3 .^{13}$

Keterbatasan pada penelitian ini ialah dari seluruh penderita karsinoma payudara lanjut lokal yang dijadikan subjek penelitian kebanyakan secara klinis (31 subjek) memiliki respon parsial berdasarkan kriteria WHO, sedangkan 5 subjek yang lain adalah 3 penderita dengan respon komplit, 1 subjek dengan tidak berespon, dan 1 subjek dengan respon progresif , sehingga pemeriksaan jumlah trombosit dan kadar D-dimmer plasma ini tidak memberikan gambaran pada respon komplit maupun penyakit progresif. 


\section{Kesimpulan}

Terdapat hubungan yang signifikan dengan korelasi positif antara perubahan volume tumor payudara, jumlah trombosit, dan kadar $D$-dimmer plasma setelah pemberian kemoterapi neoadjuvan kombinasi FAC.

\section{Saran}

Dilakukan penelitian lebih lanjut untuk mengetahui batasan nilai cut off dari jumlah trombosit dan kadar D-dimmer plasma dihubungkan dengan respon kemoterapi, sehingga jumlah trombosit dan kadar Ddimmer plasma ini dapat digunakan sebagai alternatif indikator respon kemoterapi yang lebih objektif, disamping indikator dengan pemeriksaan volume tumor secara fisik yang saat ini telah umum digumakan.

\section{Daftar Pustaka}

1. Ferlay J, Shin HR, Bray F, Forman D, Mathers C, Parkin DM. Estimates of worldwide burden of cancer in 2008 : GLOBOCAN 2008. Int J Cancer. 2010;127(12): 2893-917.

2. Direktorat Jendral Bina Pelayanan Medik Departemen Kesehatan R.I. Judul Tulisan yang diambil/sitasi? Tersedia di http://www.yanmedik-depkes@net [diperbaharui 2007; diunduh tanggal 21 Mei 2011].

3. Ramli M, Azamris, Burmansyah, Dlidir Dj, Handojo Dj, Suardi DR, et al. Panduan penatalaksanaan kanker payudara. Dalam: Manuaba IBTjW, editor. Pedoman penatalaksanaan kanker solid Peraboi. Jakarta: Sagung Seto; 2010. hal.16-23.

4. Zager JS, Solorzano CC, Thomas E, Feig BW, Babiera GV. Invasive breast cancer. In: Feig BW, Berger DH, Fuhrman GM, editors. The MD Anderson surgical oncology handbook. 4th ed. Houston: Lippincott Williams-Wilkins; 2006. p. 24.

5. Hortobagyi GN, Singletary SE, Strom EA. Treatment of locally advanced and inflammatory breast cancer. In: Harris JR, Lippman ME, Morrow M, Osborne CK, editors. Diseases of the breast. 2nd ed. Philadelphia: Lippincott Williams and Wilkins; 1999. p. 645-60.

6. Wood WC, Muss HB, Solin LJ, Olopade OI. Malignant tumors of the breast. Dalam: DeVita VT, Hellman S, Rosenberg SA, editors. Cancer principles and practice of oncology. 7th ed. Philadelpia: Lippincott Williams and Wilkins; 2005.p.1145-77, 1415-1477.

7. Cole J, Kardinal CG. Locally advanced and inflamatory breast cancer. In: Donegan \& Spratt, editors. Cancer of the breast. 5th ed. USA: Saunders; 2002.p.597-600

8. Meric-Bernstam F, Pollock RE. Oncology. In: Brunicardi CF, Andersen DK, Billiar TR, Dunn DL, Hunter JG, Matthews JB, et al. Schwartz's principles of surgery. 9th ed. USA: Mc Graw Hill Medical; 2010.p.260.

9. Holmes CE, Bambace NM, The platelet contribution to cancer progression. J Thrombosis and Haemostasis. 2011:9:237-249.

10. Verheul HMW, Pinedo HM. The importance of platelet counts and their contents in cancer. Am Assocfor Cancer Res. 2003:9:3219-3221.

11. Kumar V, Abbas AK, Fausto N. Neoplasma. Dalam: Kumar $\mathrm{V}$, Contran RS, editor. Robbins and contran pathologic basis of disease. 7th Ed. Philadelphia: Elsevier Saunders; 2005. hal.269-339.

12. Drovak FH, Frederick. Malignancy and hemostasis. In: Colman RW, Marder VJ, editors. Hemostasis and thrombosis basic principle and clinical practice. 4th ed. USA: Lippincott Williams Wilkins; 2006.p.851-67.

13. Verheul HMW, Hoekman K, Luykx-de Bakker, Eekman CA, Folman CC, Broxterman HJ, et al. Platelet: Transporter of vascular endothelial growth factor. Am Assoc Cancer Res.1997:3:2187-2190.

14. Dirix LY, Weydens R, Salgado R, Benoy L, Vermeulen P, Prove A et al. Elevated plasma D-dimer levels in progressive metastatic breast cancer correlation with tumor load and response to therapy. Asco Ann Meeting. 1999; 408.

15. Purwito J. Pengaruh kemoterapi neoadjuvan kombinasi FAC terhadap perubahan kadar D- dimer plasma dan perubahan volume tumor pada penderita karsinoma payudara lanjut lokal. Divisi Bedah Onkologi dan Kepala Leher RSHS Bandung. Tesis? Publikasi?2012.

16. Benoy H I, Salgado R, Elst H, Van Dam P, Weyler $\mathrm{J}$, Van March E, et al. Relative microvessel area of the primary tumor and lymph node status, predicts the presence of bone marrow micro metastases detected by reverse transcriptase polymerase chain reaction in patients with clinically non metastatic breast cancer. Research Article, Breast Cancer Res. 2005;7:22.

17. Thromb Houdijh PMW. Clinical application of D-dimmer. Dev Haemost. 1999;3:1-28.

18. Oya M, Akiyama Y, Okuyama T, Ishikawa H. High perioperative plasma $D$-dimmer level is associated with advanced tumor stage and short survival after curative resection in patient with colorectal cancer. Jpn Clin Oncol. 2001;31(8):38894.

19. Blackwell K, Haroon Z, Broadwater G, Berry D, Herris L, Iglehart D, et al. Plasma D-dimmer levels in operable breast 
cancer patients correlate with clinical stage and axillary lymph node status. J Clin Oncol. 2000;18:600-8.

20. Dirix LY, Salgado R, Weydens R, Colpaaert C, Huget P, Prove A et al. Plasma fibrin D-dimer levels correlate with tumor volume, progression state and survival in patients with metastatic breast cancer. Br J Cancer. 2002;86:389-95 